\title{
School Based Management at Privat Islamic Junior High School at South Jakarta
}

\author{
Arum Fatayan*, Ivan Hanafi, Eliana Sari \\ \{Arum_Fatayan@yahoo.com* \\ Universitas Negeri Jakarta, Indonesia
}

\begin{abstract}
The research is aimed to discover the implementation of school based management from It's success factors, the benefit and the constraints faced and evaluating from the compatibility of context, input process and product at privat Madrasah Tsanawiyah in south Jakarta. The method used is qualitative descriptive and CIPP evaluation. The data is gained by using document study, observation, Interview, questionaire, Field note and they were analyzed by using triangulation method and data reduction.
\end{abstract}

Keywords: MBS Evaluation, CIPP evaluation model, Privat Islamic Junior High School

\section{Introduction}

Privat Islamic Junior High School is a school which is in the same level as junior high school, but based on islamic culture. Privat Islamic Junior High School is School hich is established a privat foundation. To discover whether the managmenet at the school runs well and effective, we need an evaluation of school based management at the school. Based on the problem background, connect with some problems related to the application of School Based Management, so the factual description about collective performance of the School Based Management application that empower the headmaster, teacher, student, administration staff, society and school commitee at Privat Islamic Junior High School at south Jakarta in education administration context is an urgent phenomenon to be revealed through research.

School is an one of education institution, which hold education function. Contrast with family that also runs education function, school is a formal institution, a structured institution and hierarchical instituion from elementary, Intermediate and advance education. According to the law, UU RI No.20/2003 section 1 verse 8 about education system, education stage is an education level that is determined based on student development, the determined goal and the developed capability. Meanwhile, family is an informal education in free system. So, it is stated, school is the only institution which specifically holds education function for every citizen.

School based management is a management model which gives autonomy to school and suppory the paricipatory decision making that involve all the school member directly or Islamic School congruent with quality assurance that stated by the government. Due to the law about national education UU RI no 20/2003, it is explained that school based management is an autonomy education management in an institution where the headmaster or teachers are helped by the school commitee or society to manage the educational activity at school. In principle, school based management is aimed to empower the school to determine many 
internal policies that leads to the improvemeent of qualitu and performace development as : "The systematic decentralization to the school level of authority and responsibility to make decisions on significant matters related to school operations within a cenally determined framework of goals, policies, curriculum, standars, and accountability." [1]

The implementation of School Based Management at schoo is also one of the way to improve education or school quality. Quality is a dinamic situation relates with product, man power, process and the task also the environment that fulfill concumer needs. Educational quality is an ouyput derives from the input and teaching learning process continously. The improvement of school quality is a continous process. It improves some education factors related and the teaching learning process itself. The aim is to achieve the school goal more effective and efficient. Agustinus Bandur $\mathrm{n}$ his scientific journal entitle The implementation of school Based Management in Indonesia : Creating conflicts in regional levels, stated : reforms in public education with the successful implementation of School-Based Management (SBM) have brought about significant improvements in schools. In Indonesia, the implementation of SBM since the turn of the 21 st Century has been a strategic reform adopted as a vehicle for school improvements.[2]

The function of School Based Management is not quite different with the function of menagement in general. Islamic School is exist in education world in Indonesia because of the eagerness to balance between general kknowledge and religious knowledge. Then, many Islamic School were established. From elementary Islamic School to Intermediate level Islamic School. There are also public Islamic School and privat Islamic School which are built by local foundation. Indonesia, the world's fourth most populous nation, has been decentralizing its education sector for the past decade. In this context, school-based management is essential for improving the quality of education. A mixed-method, multisite assessment of a project that aimed to improve the management and governance of basic education in Indonesia documented positive impact on school-based management in both public and private schools, including Islamic schools.[3]

This research is focused on the sucess of the implementation of Based School Management at Islamic Junior High School in South Jakarta for quality competence among schools. Based on the problem identification, The writer limit the problem scope into Describe and explain the success level on the implementation of school based management which is applied at privat Islamic schools at south Jakarta.

\section{Method}

This research use field research, because the authors observed direct problems. This field research is a qualitative research. The procedures produce descriptive data on written and oral description from the respondent. The qualitative method is a method in which the research is not measured by numbers but descriptions. In this research, the researcher becomes instrument, That's why in qualitative research, the instrument is human. To be an instrument, the researcher should have adequate knowledge. Thus the researcher can ask, analyze, takes a picture and construct the object more clear and meaningfull.

A qualitative research is a research method which is used to explore the condition of natural object, where the researcher is the key instrument. The data collecting technique is done through triangulation, the data analysis is inductive, and the result of the research is more to emphasize the meaning better than generalization[4]. Qualitative research is a research 
which aim to understand the phenomenon about what has been undergo by the respondent. Such as: behaviour, perception, motivation, action, etc ; holistically and in sentence form in special context and by using many scientific method[5]. In this process, the writer combine descriptive method with CIPP evaluation model to fulfill research method standard. Descriptuve method is used by the researcher to describe certain object.

CIPP evaluation model is used by the evaluator more often. It's because this evaluation model is more comprehensive compare to other model. This model is developed by Daniel Stuffleabem and friends in Ohio State University. In the beginning, this model was used to evaluate ESEA. CIPP stands for Context Evaluation, Input Evaluation, Process evaluation and Product Evaluation. They are the components of evaluation

Data collection in this study uses a qualitative method that discusses the evaluation of the implementation of School-Based Management in privat junior high school after analysis is then explained in words, namely interviews, document review, observation and questions.( https://osf.io/h5ftw/ )

\section{Result and Discussion}

For The success of this research is determined by many factors. Such as : the teaching learning process, teacher competencies, the capability of the administration staff and the extra activities at school. Through the involvement of headmaster and his commitee in supervising the teaching learning process. The teachers are more professional in doing their task since the implementation of school based management is implemented. One of the requirement is that the teacher should teach 24 hours per week. The teacher also should have linierity on teaching.From the observation, it was found that almost all teachers in privat junior high school at south Jakarta have got the certification reward.

School-based management has increasingly become the agreed-upon model around the world for the operation of schools, particularly those in large public education systems. A critical element of the model is devolving enhanced levels of decision-making from the centre (eg the head office) to the schools. While the rhetoric surrounding such actions is usually acclaimed as a positive step for teachers, parents and the wider community to be involved in decisions that affect their children. [6]

Some advantages of implementing School Based Management are that the school has autonomy to determine their activity and responsible for it. So, the school can improve the wealthness of teachers and make the teachers more focus on their duties. The freedom in managing the resources makes the headmaster more capable and professional on doing his duties. The headmaster and team can also arrange the curriculum, to make the teachers more innovative and doing many support activities at school environment. We can say that School based Management support the teahers and headmasterss' capabilityand profesionalism at school. By arranging the effective curiculum, the educational service will increase for the teachers and parents maximumly.

In the begining, the headmaster toghether with the school supervisor gave held a a small workshop to the teachers. But not all the teachers eager to join the activity because they thought that it would be a burden for them besides teaching duty in the class. school based manajemen is a research based, communited, structured, and decentralized method of operating the school district within understood parameters and staff roles to maximize resource, effectiveness by transferring the prepoderant shere of the entire school system's 
budget, along with corresponding decision making power, to the local schools on an equitable tump sum basis, based upon a differentiated per pupil allocation to be spent irrespective of source in the best interests of the students on those schools according to a creative local school plan and local school budget developed by the stake holders, approved by the superintendent ; such plans being designed to achieve approved goals of improving education by placing accountability at the individual school, and evaluated more by results than by methodology.

The effective schools movements began in the late 1970s and early 1980s with studies by ronald edmonds of harvard university. Edmonds defined effective of strategi schools as schools in wich student achievement schores (and order indicators of students seccess) did not vary by socloeconomic status. He associated five characteristics with effective schools:1. Strong leadership by the principal, 2. High expectations of students performence, 3. An emphasis on basic skills and 4. An orderly and controlled atmosphere, 5. Frequent testting of students performancey.[7]

The inefficient decision wich is done participatory could gives some stress and make it slower, compare to otoratic ways. The member of the committe should be cooperate and focus their attention on their tasks. The head master may not take his own decision on any activities without coordinating with the person in charge

\section{Conclusion}

From the explanation, it can be concluded. That the succed of the implementation of school based management are :

1. A planned program will not be succes maximize if there are no supported factors. The support factors could be from internal or external.

2. Autonomy gives the school member to be responsible to manage the resources and develop the school based management strategy fit to the conditon of school.

3. Trough controlling from the society and goverment monitoring, the management of school becomes more accountable, transparant, egaliter and democratic.

4. School development must be based on it's potential.

5. The strategy to increase education is by delegating the authority of making important decision from centre to local at school level.

6. Give chance for bigger controlling to headmaster, teachers, students, and parents on education process.

7. The responsible of decision making on financial,human resources and curriculum placed at school level, not at the centre level.

8. School can move more free on managing the education system which fits to the society need as the school knows the condition of the school better.

9. School has the autonomy to hold better and adequate education system for the students. Autonomy in management is potential for the school to increase the performance of school staff, Offering direct participation to related groups, and increase the understanding about educatulion to the community. 


\section{References}

[1] R. J. Caldwell, School-based Management. USA: UNESCO, 2003.

[2] A. Bandur, "The Implementation of School-Based Management in Indonesia: Creating conflicts in regional levels," Journal of NTT Studies., vol. 1, pp. 16-27, 2009.

[3] M. Heyward, R. A. Cannon, and Sarjono, "Implementing School-Based Management in Indonesia," RTI Press publication OP, 2009.

[4] A. R. A. Ghani, Mengurai Simpul Pendidikan. Jakarta: Uhamka Press, 2009.

[5] L. J. Moleong, Metode Penelitian Kulitatif. Bandung: Rosdakarya, 2001.

[6] C. C. Neil, "Collaborative decision-making and school-based management: challenges, rhetoric and reality," Journal of Educational Enquiry, vol. 22001.

[7] Jossey, School Based Management (organizing for high performence. San Fransisco: Bas Publisher, 1994. 